population brought about by the War, and the extent to which this redistribution was likely to persist in the post-war period; into the effects of war conditions on the working of publie social services (other than the hospital service); into the changes in conditions of living due to evacuation and similar measures taken to meet the war situation, and into the bearing of all these factors on the general problem of national reorganization after the War. The bulk of the expenses of the survey during the current financial year will be borne by the independent resources of Nuffield College, but the Government has undertaken to make a grant not exceeding $£ 5,000$ towards the expenses of the Survey in that year.

\section{Provision of Fine Chemicals}

REFERENCE has already been made to the scheme inaugurated by the Advisory Research Council of the Chemical Society to facilitate the supply of fine chemicals needed for work of national importance, but which are not available commercially. The subcommittee organizing this work particularly desires to direct the attention of all users of fine chemicals to the existence of this scheme, in order that the greatest possible use may be made of the generous offers of help which have been received from numerous chemists in universities, technical colleges and schools, who have suitable laboratory facilities at their disposal. The scheme, which works in close collaboration with the Association of British Chemical Manufacturers, is an attempt to use to the best possible advantage both the laboratory facilities and the skilled man-power in teaching institutions and other laboratories which may not at present be fully harnessed to the war effort.

Before a substance can be accepted for preparation under this scheme, the Committee must be satisfied that the chemical is unobtainable from any British manufacturing firm and that it is required for urgent work of national importance within the British Empire. The scheme provides for the manufacture of approved items at basic charges which represent only the cost of raw material and such overheads as gas, electricity, etc. There is no charge for the chemist's services. Inquiries from both individuals and firms for chemicals which might be produced under the scheme should be made to the Secretary, Mr. S. E. Carr, Chemical Society, Burlington House, Piccadilly, London, W.1.

\section{War and Industry in India}

Comments on the relation of industry in India to the country's war effort are made in an article by J. C. Ghosh in the February issue of Current Science. Mr. Ghosh believes that Indian nationalists have a genuine grievance against the Government for lack of vision in dealing with industrial development. During the War of 1914-18, much encouragement was given to many new industries, and, in the postwar years, it was withdrawn on the grounds that only those industries likely to become independent of State support should be supported. Thus the industries commanding an abundant supply of raw material and a ready market for finished products, such as cotton, paper and cement, have gone ahead; unfortunately, this gain has been offset by decreasing prices and shrinking foreign markets for agricultural products. Mr. Ghosh's remedy for this state of affairsand he thinks it is also a means of assisting defence measures-is to establish as key industries those which are included under the broad heading of metallurgical, engineering and machine tools, chemical and transportation industries.

Mr. Ghosh then discusses what has already been done in these fields. The Tata concern has been responsible for large developments in the iron and steel industry, and it is claimed that India could supply all the steel requirements of the countries represented at the Eastern Group Conference. Nonferrous industries are not so advanced, but a plant for the production of aluminium with a capacity of 5,000 tons a year is being erected. Engineering is also backward. The heavy chemical industries are developing and may soon satisfy a large part of the country's requirements, but the dye-stuff and fine chemical industry is not satisfactory. The production in India is also urged of locomotives, ocean-going vessels and aeroplanes. It is stated that Indian industrialists fear that the manufacture of motorvehicles is too difficult to be undertaken by Indian workmen in the near future, forgetting that "the thought and skill required in manufacture have been transferred from workmen to automatic machines". Non-official opinion in India is said, however, to be strongly in favour of starting such industries, and maintaining them as a part of the defence programme of the country.

\section{Health of the Army in India}

According to the annual report for 1939 on the health of the Army in India, there were no serious epidemics during the year among British or Indian troops, although civilian areas in which troops were placed suffered from cholera, plague, small-pox, dysentery, malaria and enterie fever. The hospital admission-rate among British troops was as large as 666 per 1,000 of strength during the year, and was an increase on the rate for the previous year, but the death-rate of 2.75 per 1,000 and the invalidingrate of 9.14 per 1,000 were lower. Among the Indian troops the death-rate was also down, but the hospital admission- and invaliding-rates were up. This increase, however, was undoubtedly due to the eonditions of war service and the return or influx of large numbers of men potentially infected with malaria and other prevalent diseases. Malaria and dysentery held the first place in the list of principal causes of sickness among British officers, and were followed by cellulitis and catarrhal jaundice. Malaria also held the chief place among soldiers, and next came cellulitis, and a good way down tonsillitis; but dysentery came sixth and was only half as frequent as a cause of admission as malaria. The prevalence of dysenteric infections was found to be due to lack of sanitation surrounding the troops' area. Respiratory diseases 